\title{
Urban Land uses as Catalysts to Ambient Air Quality Degradation in the Metropolitan City of Calabar, Nigeria
}

\author{
Josiah Nwabueze Obiefuna ${ }^{1 *}$, Ebin Oka Inah ${ }^{2}$, Iheoma Iwuanyanwu ${ }^{3}$, Etim Omini Eteng ${ }^{4}$ \\ ${ }^{1}$ Department of Geography and Environmental Science, Faculty of Environmental Sciences, University of \\ Calabar, P.M.B. 1115, Calabar-Nigeria. Email: JoeObiefuna@Unical.edu.ng: \\ ${ }^{2}$ Department of Geography and Environmental Science, Faculty of Environmental Sciences, University of \\ Calabar, P.M.B. 1115, Calabar-Nigeria. Email: Ebin.inah@unical.edu.ng \\ ${ }^{3}$ Department of Geography and Environmental Science, Faculty of Environmental Sciences, University of \\ Calabar, P.M.B. 1115, Calabar-Nigeria. Email: Omaiwuanyanwu@ yahoo.com \\ ${ }^{4}$ Department of Geography and Environmental Science, Faculty of Environmental Sciences, University of \\ Calabar, P.M.B. 1115, Calabar-Nigeria. Email: Etimeteng89@gmail.com \\ *Corresponding Author: JoeObiefuna@Unical.edu.ng, JoeObiefuna@ GMail.com
}

Received Date : January 02, 2022 Accepted Date : January 28, 2022 Published Date : February 07, 2022

\begin{abstract}
This study examined urban landuses as catalysts to ambient air quality problems in Calabar metropolis, Nigeria. Data on emission level of $\mathrm{CO}$, $\mathrm{NO}_{2}, \mathrm{SO}_{2}, \mathrm{H}_{2} \mathrm{~S}$, and SPM2.5 were acquired using Gasman, while point coordinates were collected using Garmin GPSMap 60CSx device. Student's ttest statistics and Analysis of Variance (ANOVA) were employed to test the hypothesis. From findings, the null hypothesis was rejected for all the test parameters $\left(\mathrm{CO}, \mathrm{NO}_{2}, \mathrm{SO}_{2}, \mathrm{H}_{2} \mathrm{~S}\right.$, and $\mathrm{SPM}_{2.5}$ ) because it could not be concluded that the concentration of parameters measured were higher than the FEPA permissible limits for all the parameters. In order to help identify which ones were significantly higher or lower, the column of mean difference and $\mathrm{t}$-value, where the mean difference is on the negative was consulted. This means that the concentration of the parameters in the air was within the FEPA permissible limits. Where that is the case, the calculated t-value is also negative. It should be noted that automated calculation of student's t-statistics with the SPSS does not make use of the modulus sign. The use of modulus ignores the sign in statistical analysis. For this present student, the result for $\mathrm{CO}$ and $\mathrm{H}_{2} \mathrm{~S}$ are within the acceptable limits while those for $\mathrm{NO}_{2}$, $\mathrm{SO}_{2}$ and $\mathrm{SPM}_{2.5}$ are higher than the acceptable limits. It was therefore recommended that there should be protection of the residential land uses to avoid encroachment by incompatible uses which cause pollution. Finally, green areas should be protected due to their potentials as urban green lungs.
\end{abstract}

Key words : Air quality, blight, landuses, pollution, disaster

\section{INTRODUCTION}

It has been proven that as cities grow numerically, physically and functionally, an increase in energy consumption, industrial effluents, vehicular traffic and noise become unavoidable [1]-[3]. Ultimately, these would obviously impact negatively on the quality of air [4]-[9]. They also believe that weather parameters, anthropogenic and biological emissions under some growth scenarios affect air quality leading to related disaster. However, these studies did not compare air quality in the study area with safe standard in order to ascertain whether it is within the acceptable limit.

The Nigerian environment is continually, progressively and seriously susceptible to several environmental problems such as pollution of water, air, land, erosion, climate change, global warming, biodiversity loss and desert encroachment among others. Notably, air quality concern is principal focus for long term planning.

Air pollution engineered by conditions such as uncontrolled discharge of waste in residential areas, increased vehicular movement along transportation routes, amorphous development of informal enterprises and increased industrial activities, is the major characteristics of Calabar Metropolitan city. However, to manage human activities in aggregate terms, it is pertinent to know the level or concentration of pollutants being generated in Calabar metropolis. These cannot be known if pollutants level is not measured. 
Finally, since economic activities constitute or result to pollution of varying degree, it is pertinent that various land uses in Calabar Metropolis which represent diverse economic activities be scrutinized for various pollutants to ensure that they conform to acceptable standards, otherwise, the people and property would be endangered.

\section{STATEMENT OF THE RESEARCH PROBLEM}

Studies [1]-[9] examined ambient air quality on a spatial and temporal scale globally and regionally. Unfortunately, in Calabar metropolis, air quality related studies are scanty. The metropolis is generally seen as lacking heavy industries and that no form of gas flaring or oil related upstream activities are being carried out. However, a lot of economic activities capable of impacting on air quality are constantly on the increase due to urbanization and the dynamic nature of the city. Industrial, transportation, commercial and other anthropogenic activities result to emission of effluents and degradation of air quality and human lives. Consequently, this calls for the need for a robust and constant air quality assessment in the metropolis, especially, with its nomenclature as a tourism destination inundated with several relaxation hotspots and economic activities. This research therefore aimed at monitoring air quality status in order to compare and ensure that it conforms to the acceptable threshold/standards, otherwise, the people and property would be endangered.

\section{AIM AND OBJECTIVES OF THE STUDY}

The aim of this research was to examine urban land uses as catalysts to ambient air quality issues in Calabar Metropolis, Nigeria. The objective was to determine the ambient air quality status in relation to existing land uses in Calabar Metropolis and compare it with safe standards.

\section{RESEARCH HYPOTHESIS}

$\mathrm{H}_{0}$ : Ambient air quality in Calabar Metropolis is not significantly different from the Federal Environmental Protection Agency, FEPA 1991 permissible threshold [10].

\section{THE STUDY AREA}

This study was carried out in the capital city of Cross River State, known as Calabar (Figure.1). Calabar is located between longitudes $8^{\circ} 18^{\prime}$ and $8^{0} 25^{\prime \prime}$ East of the Greenwich meridian and latitudes $4^{\circ} 55^{\prime}$ and $5^{\circ} 10^{\prime}$ North of the Equator. It is sandwiched between the Great Kwa River to the East and the Calabar River to the west.

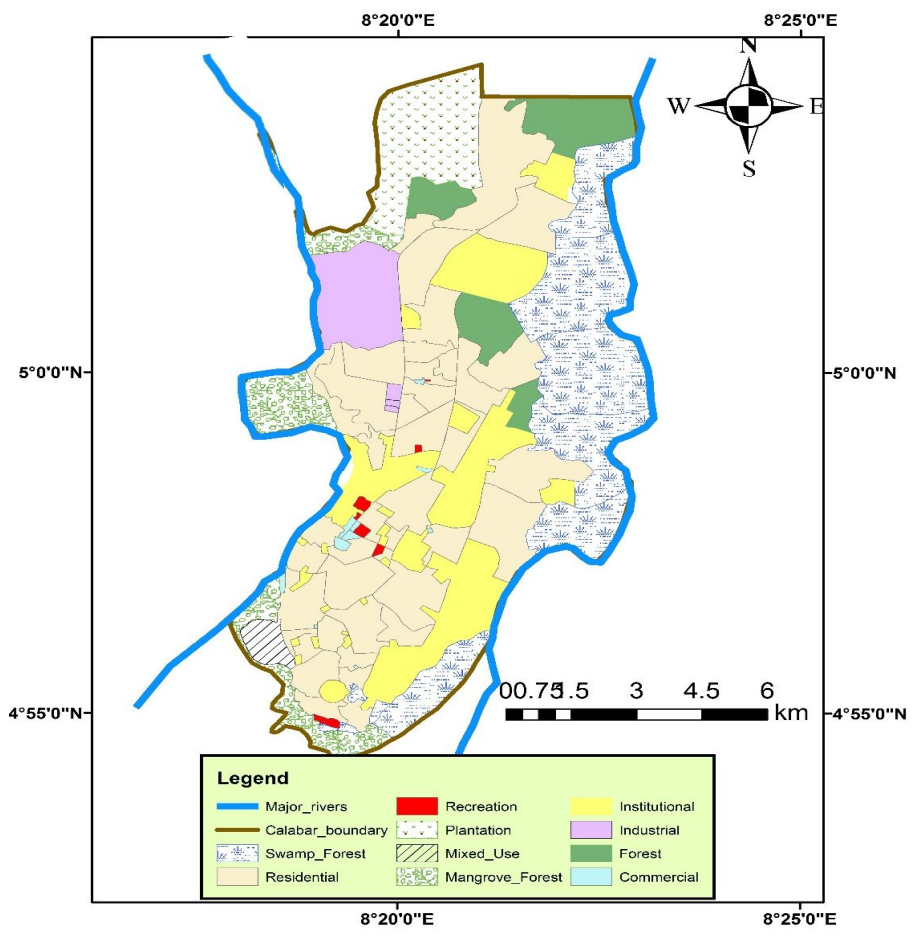

Figure.1: Land use map of Calabar Metropolis showing the study area Source: [4]

Calabar Metropolis, which is made up of Calabar Municipality and Calabar South Local Government Areas, covers an area of $1480 \mathrm{sqkms}$. Calabar is bounded to the North by Odukpani Local Government Area and to the East by Akpabuyo Local Government Area.

\section{RESEARCH METHODOLOGY}

During recognizance, GPS data were acquired using a Garmin GPSmap 60CSx. Air quality data for this study were made up of continuous variables in the form of air quality readings for 5 parameters from various land uses such as industrial, transportation, commercial and residential. They were acquired using automated real-time data loggers such as Crowcon Gasman. In a more specific term, the study relied on data on ambient air quality status in Calabar Metropolis as well as air quality threshold data from FEPA, Nigeria; data on air quality status across various land uses as well as data on seasonality differential in air quality status. Data were expressed in parts per million (ppm) scale. Besides, land use maps of the study area as well as the real-time Google earth imagine data were also consulted.

\section{ANALYTICAL PROCEDURE}

Hypothesis one

$\mathrm{H}_{0}$ : Ambient air quality in Calabar Metropolis is not significantly different from FEPA, (1991) permissible threshold. 
$\mathrm{H}_{1}$ : Ambient air quality in Calabar Metropolis is significantly different from FEPA, (1991) permissible threshold.

This hypothesis was tested using one-sample student's t-test statistics. The t-test statistics was designed to test if the mean for a sample is significantly different from a specified value [11]. The specified value in this case is the FEPA air pollutants permissible limits for each of the measured parameters. The mathematical definition of the t-test statistics is given as:

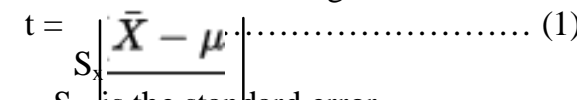

Where $S_{\mathrm{x}}$ is the standard error

$\bar{X}$ s the mean of the samples from a sample

$X_{1}, X_{2}, \ldots, X_{n}$, of size $n$

$\mu$ is the specified numeric value (FEPA limit).

The reason for its use is due to its ability to determine whether or not there is a statistically significant difference between the means of two datasets. The test was conducted as a 2-tailed since it was not clear where the direction of the test would be.

\section{AMBIENT AIR QUALITY STATUS IN CALABAR METROPOLIS AND FEPA SAFE STANDARDS.}

Table 1 presents summary statistics for measured parameters across Calabar Metropolis. From the table, the mean and standard deviation for $\mathrm{CO}$ is $2.68 \mathrm{ppm}$ and 1.051 respectively. For $\mathrm{NO}_{2}$, the values are 1.06ppm and 1.040. Besides, the values for $\mathrm{SO}_{2}$ are $1.37 \mathrm{ppm}$ and 1.170 while for $\mathrm{H}_{2} \mathrm{~S}$, they were $1.21 \mathrm{ppm}$ and 1.095 . Finally, the values for SPM 2.5 were $3.22 \mathrm{ppm}$ and 1.072 respectively. The number of cases for the observation was 3198 . The main data is presented in appendix 1a and appendix $1 \mathrm{~b}$.

Table 2 highlights the stipulated standard by FEPA or FMEV, Nigeria. As shown on the table, it is expected that effluents emitted in urban areas should not be beyond the figures, otherwise, the urban environment would be considered as unsafe for human habitation. For sustainability to be achieved, it is recommended that emissions level be juxtaposed to the established threshold as a measure of conformity.

Table 1: Summary statistics for measured parameters across Calabar Metropolis Source: Author's analysis, 2020.

\begin{tabular}{lccc}
\hline Parameters & Mean & S.D. & No. of cases \\
\hline $\mathrm{CO}$ & 2.6826 & 1.05139 & 3198 \\
$\mathrm{NO}_{2}$ & 1.0687 & 1.03977 & 3198 \\
$\mathrm{SO}_{2}$ & 1.3745 & 1.16985 & 3198 \\
$\mathrm{H}_{2} \mathrm{~S}$ & 1.2094 & 1.09490 & 3198 \\
$\mathrm{SPM}_{2.5}$ & & & 3198 \\
& 3.2234 & 1.07232 & \\
\hline
\end{tabular}


Table 2: FEPA air pollutants permissible threshold

\begin{tabular}{lll}
\hline POLLUTANTS & SYMBOL & FEPA STANDARDS \\
\hline Carbon Monoxide & $\mathrm{CO}$ & $10-20 \mathrm{ppm}$ \\
Nitrogen Dioxide & $\mathrm{NO}_{2}$ & $0.06(113 \mathrm{mg} / \mathrm{m} 3)$ \\
Sulphur Dioxide & $\mathrm{SO}_{2}$ & $0.1 \mathrm{ppm}$ \\
Hydrogen Sulphide & $\mathrm{H}_{2} \mathrm{~S}$ & 8.0 \\
& & \\
Suspended Particulate Matter & $\mathrm{SPM} 2.5$ & $0.25\left(250 \mathrm{mg} / \mathrm{m}^{3}\right)$ \\
& & \\
\hline
\end{tabular}

Source: [10], [12].

\section{ANALYSIS AND DISCUSSION OF FINDINGS}

$\mathrm{H}_{0}$ : Ambient air quality status in Calabar Metropolis is not significantly different from FEPA, (1991) permissible threshold.

$\mathrm{H}_{1}$ : Ambient air quality status in Calabar Metropolis is significantly different from FEPA, (1991) permissible threshold.

This hypothesis was tested based on individual parameters using the student's t-test parametric statistics. Table 3 shows the summary results from test of hypothesis one. From the result as shown, the null hypothesis was rejected for all the test parameters $\left(\mathrm{CO}, \mathrm{NO}_{2}, \mathrm{SO}_{2}, \mathrm{H}_{2} \mathrm{~S}\right.$, and $\left.\mathrm{SPM}_{2.5}\right)$. from the result, it could not be concluded that the concentration of parameters measured were higher than the FEPA permissible limits for all the parameters. In order to help identify which ones were significantly higher or lower, the column of mean difference and $\mathrm{t}$-value, where the mean difference is on the negative is consulted. This means that the concentration of the parameters in the air was within the FEPA permissible limits. Where that is the case, the calculated t-value is also negative. It should be noted that automated calculation of student's tstatistics with the SPSS does not make use of the modulus sign. The use of modulus ignores the sign in statistical analysis. For this present student, the result for $\mathrm{CO}$ and $\mathrm{H}_{2} \mathrm{~S}$ are within the acceptable limits while those for $\mathrm{NO}_{2}, \mathrm{SO}_{2}$ and $\mathrm{SPM}_{2.5}$ are higher than the acceptable limits.

\section{CONCLUSION}

This study examined urban landuses as catalysts to ambient air quality issues in Calabar metropolis, Nigeria. The Major objective was to determine the ambient air quality status in Calabar Metropolis and compare it with safe standards. 
Table 3 :Summary of results from test of hypothesis one.

\begin{tabular}{|c|c|c|c|c|c|c|c|c|c|}
\hline Parameter & $\mathrm{N}$ & Mean & $\begin{array}{l}\text { Std. } \\
\text { Dev }\end{array}$ & $\begin{array}{l}\text { Mean } \\
\text { Diff. }\end{array}$ & t-Value & $\mathrm{df}$ & $\begin{array}{l}\text { Sig. } \\
(2 \\
\text { tailed })\end{array}$ & $\begin{array}{l}\text { FEPA } \\
\text { Standard } \\
\text { Value }\end{array}$ & Remarks \\
\hline $\mathrm{CO}$ & 3198 & 2.6826 & 1.05139 & $\begin{array}{l}- \\
17.31744\end{array}$ & $\begin{array}{l}- \\
935.232\end{array}$ & 3197 & $0.000^{* *}$ & 20 & $\begin{array}{c}\text { Ho } \\
\text { Rejected }\end{array}$ \\
\hline $\mathrm{NO}_{2}$ & 3198 & 1.0687 & 1.03977 & 1.00867 & 55.082 & 3197 & $0.000^{* *}$ & 0.06 & $\begin{array}{c}\text { Ho } \\
\text { Rejected }\end{array}$ \\
\hline $\mathrm{SO}_{2}$ & 3198 & 1.3745 & 1.16985 & 1.27447 & 61.858 & 3197 & $0.000^{* *}$ & 0.1 & $\begin{array}{c}\text { Ho } \\
\text { Rejected }\end{array}$ \\
\hline $\mathrm{H}_{2} \mathrm{~S}$ & 3198 & 1.2094 & 1.09490 & -6.79056 & $\begin{array}{l}- \\
352.152\end{array}$ & 3197 & $0.000^{* *}$ & 8 & $\begin{array}{c}\text { Ho } \\
\text { Rejected }\end{array}$ \\
\hline SPM 2.5 & 3198 & 3.2234 & 1.07232 & 2.97342 & 157.445 & 3197 & $0.000^{* *}$ & 0.25 & $\begin{array}{c}\text { Ho } \\
\text { Rejected }\end{array}$ \\
\hline
\end{tabular}

** Difference is significant at $<0.001$ (2-tailed)

Source: Author's analysis, 2020

The hypothesis compared ambient air quality in Calabar Metropolis vis-avis, FEPA, (1991) permissible threshold. The null hypothesis which states that ambient air quality in Calabar Metropolis is not significantly different from FEPA, (1991) permissible threshold was rejected for all the test parameters $\left(\mathrm{CO}, \mathrm{NO}_{2}, \mathrm{SO}_{2}, \mathrm{H}_{2} \mathrm{~S}\right.$, and $\mathrm{SPM}_{2.5}$ ), since the direction of the test was not specified in the hypothesis, it could not be concluded that the concentration of parameters measured were higher than the FEPA permissible limits for all the parameters. This means that the concentration of the parameters in the air was lower than, or rather within the FEPA permissible limits. However, the result for $\mathrm{CO}$ and $\mathrm{H}_{2} \mathrm{~S}$ are within the acceptable limits while those for $\mathrm{NO}_{2}$, $\mathrm{SO}_{2}$ and $\mathrm{SPM}_{2.5}$ are higher than the acceptable limits.

This study has been able to establish the relationship between urban land uses and ambient air quality status in Calabar Metropolis, Nigeria.

\section{RECOMMENDATION}

Based on the findings of this research, certain mitigatory measures are therefore recommended for the purpose of ensuring a sustainable, clean and green Calabar Metropolis.
1. Residential zones should be exclusively maintained so as to avoid encroachment of incompatible uses which could lead to pollution and blight. Residential zones that have already been encroached, depending on the form of encroachment, should be reclaimed. For example, multiple exit routes should be closed to discourage motorists from using such as alternative routes to other destinations thereby, causing heavy traffic and congestion and pollution.

2. Open spaces and gardens should be well maintained, preserved and protected due to their potentials in sanitizing the air by acting as green lungs.

3. There is need for a periodic and real-time monitoring and envisioning of air quality status to ensure adequate and strict compliance with standards. This would help in the enforcement of related codes once violated. It would be very helpful in the continuous acquisition of more robust datasets that could be used in pre-emptive planning of the metropolis in favour of clean air act.

\section{ACKNOWLEDGMENT}

I hereby acknowledge the Department of Geography and Environmental Science for making its GIS laboratory available for this research. 


\section{REFERENCES}

[1] J. N. Obiefuna, F. E. Bisong and E. B. Ettah. A GIS Analysis of Noise Islands in Calabar Metropolis, Nigeria. Journal of Environment and Earth Science, vol. 3, No.12, pp.1-8, 2013

[2] J. N. Obiefuna and G. N. Njar. The Spatio-Temporal Distribution of Urban Noise Islands in Calabar Metropolis, Nigeria. International Journal of Scientific \& Engineering Research vol. 9, No.3: pp. 216-226, 2018

[3] J. N. Obiefuna, J. B.Kubua and C. J. Obiefuna. Acoustic Over-Exposure versus Human Health: A Case Study of Dangote Flour Mill, Calabar, Cross River State, Environmental Pollution and Protection vol. 3, No.1 pp.1-12, 2018

[4] J. N. Obiefuna, G. N. Njar and F. E. Bisong. Regional Trend in Ambient Air Quality Footprints in Calabar Urban, Nigeria, Environment and Ecology Research, vol. 9, No. 4, pp. 173 - 185. DOI: 10.13189/eer.2021.090405, August 2021

[5] J. N. Obiefuna, E. O. Inah, J. W. U. Atsa and E. A. Etim. Geospatial Assessment of Ambient Air Quality Footprints in Relation to Urban Landuses in Nigeria. Environment and Ecology Research, vol. 9, No,6, pp. 426-446. DOI: 10.13189/eer.2021.090609, December 2021

[6] A. Faniran and A. T. Adeboyejo. Environmental education and awareness for effective environmental protection and management in Nigeria. Journal of the Nigeria Institute of Town Planners, vol.12, pp.1-13, 1999

\section{Appendix}

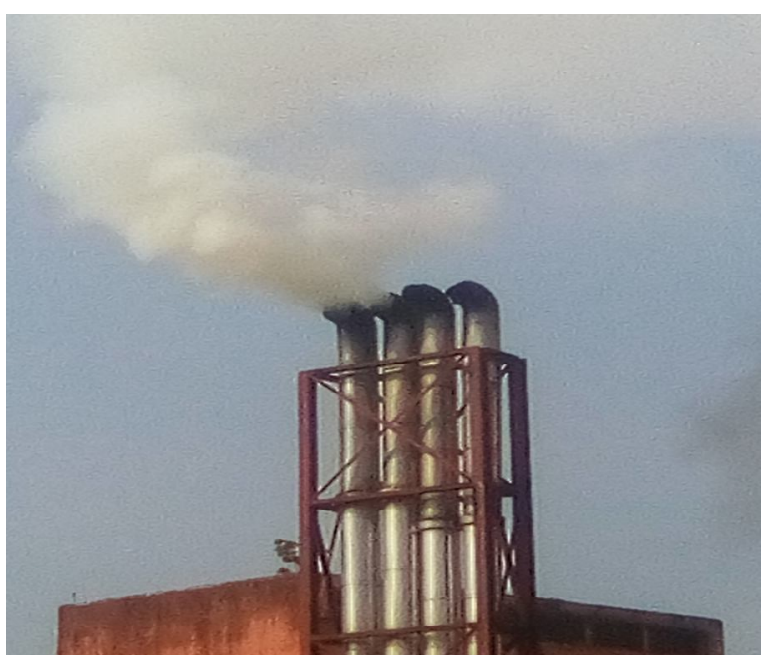

Plate 1. Generators as point sources of pollution

Source: by the author, 2021
J. Kahyaoglu-Koracin,S. D. Basset, D. A. Mouat and A.W. Gertler. Application of a scenario-based modeling system to evaluate the air quality impacts of future growth. Atmospheric Environment, vol.43, pp. 1021-1028, 2009

[8] K. Civerolo, C. Hogrefe, B. Lynn, J. Rosenthal, J. Y. Ku, W. Solecki, W, Cox, C. Small, C. Rosenzweig, R. Goldberg, K. Knowlton and P. Kinney. Estimating the effects of increased urbanization on surface meteorology and ozone concentrations in the New York City metropolitan region. Atmospheric Environment, vol 41 No.9, pp.1803-1818, 2007

[9] J. Song, B. Parmenter, A. Webb, D. Allen and E. McDonald-Buller. Impacts of urbanization on emissions and air quality: Comparison of four visions of Austin, Texas. Environmental Science and Technology, vol. 42,No.19, pp. 7294-7300, 2008

[10] Federal Environmental Protection Agency. National interim guidelines and standards for industrial effluents, gaseous emissions and hazardous wastes. Environmental pollution control handbook. Lagos: FEPA, pp. 33-63, 1991

[11] J. Efiong and E.B. Eze. Effluent discharge and strain pollution by a rubber factory: a case of field 20 stream in Odukpani, Cross River State. African Journal of Educational Studies in Mathematics and Sciences, vol. 2 No.2, pp.79-90, 2004

[12] A. Jerome. Use of economic instruments for environmental management in Nigeria. Paper presented at workshop on environmental management and administration in Nigeria (NCF.MA). 2000

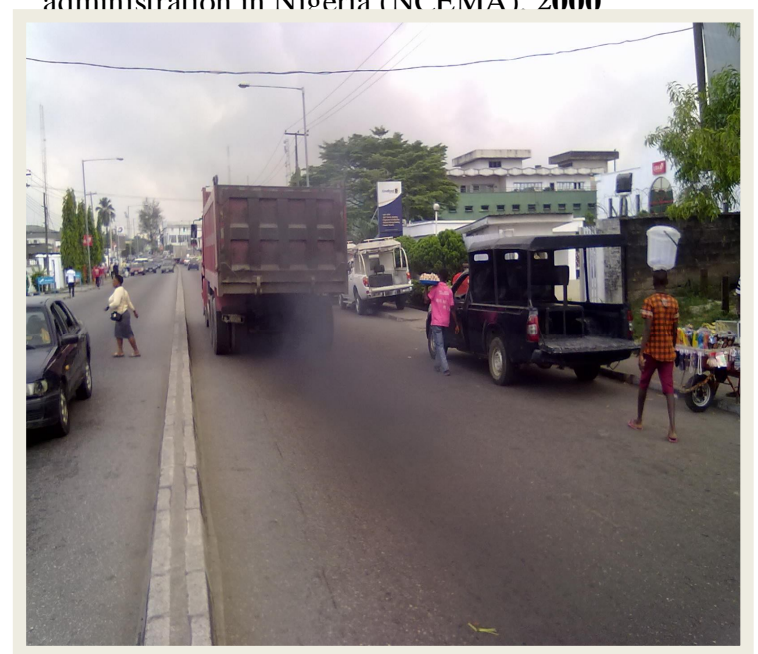

Plate 2. Automobiles as line sources of pollution

Source: by the author, 2021 